\title{
PERJANJIAN TENAGA KERJA INDONESIA YANG BEKERJA DI LUAR NEGERI DAN PERLINDUNGAN HUKUMNYA
}

\author{
Arief Wisnu Wardhana \\ ariefwisnu1960@gmail.com
}

\begin{abstract}
Abstrak
Kerangka perlindungan hukum bagi tenaga kerja Indonesia baik yang disampaikan dan diajukan pada $A S E A N, I O C$ ataupun $I L O$ dapat diimplementasikan dalam kerangka bilateral, sehingga perjanjian kerja internasional meliputi pihak Indonesia yang meliputi PPTKIS dan Pemerintah Indonesia, dan pihak di mana tenaga kerja Indonesia bekerja diwakili oleh Pemerintah negara penerimaan untuk memberikan perlindungan hukum. lemahnya perlindungan hukum yang dimuat dalam perjanjian kerja. Karena perjanjian hanya dibuat antara calon tenaga tenaga kerja dengan Perusahaan Jasa Tenaga Kerja Indonesia yang dibuat tidak berdasarkan standar perjanjian kerja internasional. konstruksi hukum perjanjian kerja acapkali tidak memberikan rasa keadilan khususnya bagi tenaga kerja Indonesia yang bekerja di luar negeri. Adapun permasalahannya sebagai berikut: 1.Bagaimanakah bentuk perjanjian kerja tenaga kerja Indonesia yang bekerja di luar negeri? 2.Bagaimanakah perlindungan hukum terhadap tenaga kerja Indonesia yang bekerja di luar negeri? Jenis penelitian yang digunakan dalam penelitian ini adalah penelitian hukum normatif yang mengutamakan data sekunder.Kesimpulan dari penelitian ini adalah 1.Bentuk perjanjian kerja tenaga kerja Indonesia yang bekerja di luar negeri berbentuk perjanjian kerjasama penempatan merupakan dasar utama perjanjian yang harus dilakukan pada setiap ingin melakukan penempatan tenaga kerja Indonesia ke luar negeri. Hal ini didasarkan pada Pasal 27 UU No. 39 Tahun 2004 mengatur mengenai penempatan baru dapat dilakukan bila Pemerintah Indonesia telah membuat perjanjian tertulis dengan pemerintah negara tujuan. 2.Perlindungan hukum terhadap tenaga kerja Indonesia yang bekerja di luar negeri adalah dimulai dengan perlindungan di dalam negeri yang dilakukan oleh Direktorat Perlindungan dan Advokasi adalah pencegahan dan penindakan terhadap Tenaga Kerja Indonesia non prosedural yang dilakukan melalui sweeping terhadap pelaksana penempatan Tenaga Kerja Indonesia non prosedural. Perlindungan hukum dan mediasi penyelesaian masalah Tenaga Kerja Indonesia yang telah dilakukan oleh pemerintah melalui tindakan preventif-antisipatif.
\end{abstract}

\section{Kata Kunci: Perlindungan Hukum, PPTKIS, PJTKI}

\begin{abstract}
The legal protection framework for Indonesian workers both submitted and proposed to ASEAN, IOC or ILO can be implemented in a bilateral framework, so that international labor agreements include the Indonesian side which includes PPTKIS and the Government of Indonesia, and parties where Indonesian workers work are represented by the Government of the country acceptance to provide legal protection. weak legal protection contained in the work agreement. Because agreements are only made between prospective workers and the Indonesian Manpower Services Company which are made not based on international labor agreement standards. Legal construction of labor agreements often does not provide a sense of justice especially for Indonesian workers who work abroad. The problems are as follows: 1. What is the form of the employment agreement for Indonesian workers who work abroad? 2. What is the legal protection of Indonesian
\end{abstract}


workers working abroad? This type of research used in this study is a normative legal research that prioritizes secondary data. The conclusions of this study are 1. The form of employment agreements for Indonesian workers working abroad in the form of placement cooperation agreements are the main basis of the agreement that must be done on every wish to place Indonesian workers abroad. This is based on Article 27 of Law No. 39 of 2004 regulating the placement can only be done if the Government of Indonesia has made a written agreement with the government of the destination country. 2. Legal protection for Indonesian workers working abroad is started with domestic protection carried out by the Directorate of Protection and Advocacy, which is the prevention and enforcement of Indonesian non-procedural Workers through sweeping of implementing non-procedural Indonesian Workers. Legal protection and mediation of the resolution of problems of Indonesian Workers that have been carried out by the government through preventiveanticipatory measures.

Keywords: Legal Protection, PPTKIS, PJTKI.

\section{PENDAHULUAN}

Perlindungan tenaga kerja harus diatur pada saat perjanjian kerja tersebut dilahirkan. Hal ini sangat penting khususnya bagi para pekerja untuk dapat memperoleh perlindungan hukum ketika hak-hak pekerja tidak dapat ditegakkan dan atau ketika para pekerja mengalami masalah terkait dengan tuntutan hukum khususnya tuntutan pidana. Dalam hal yang demikian ini, konstruksi perjanjian kerja berperan penting, khususnya klausula perjanjian kerja. Hal ini sebagaimana ditegaskan dalam Pasal 4 huruf c Undang-Undang No. 13 Tahun 2003 tentang Ketenagakerjaan yang menyatakan sebagai berikut, "memberikan perlindungan kepada tenaga kerja dalam mewujudkan kesejahteraan;". Apa yang ditegaskan dalam Pasal 4 huruf c Undang-Undang No. 13 Tahun 2003 di atas menegaskan bahwa setiap perjanjian kerja yang lahir harus terdapat klausula perlindungan hukum. Bentuk perlindungan hukum bagi tenaga kerja Indonesia ditegaskan dalam Pasal 3 huruf b UndangUndang No. 39 Tahun 2004 tentang Penempatan dan Perlindungan Tenaga Kerja Indonesia di Luar Negeri menyatakan, Menjamin dan melindungi calon TKI/TKI sejak di dalam negeri, di negara tujuan, sampai kembali ke tempat asal di Indonesia. Oleh karena itu, konstruksi hukum Pasal 4 ayat c Undang-Undang No. 13 Tahun 2003 jo Pasal 3 huruf c Undang-Undang No. 39 Tahun
2004 di atas menjadi dasar pertimbangan perjanjian kerja untuk tenaga kerja yang bekerja ke luar negeri adalah kesejahteraan. Pengertian kesejahteraan tidak hanya bersifat fisik belaka melainkan sejahtera bersifat non fisik, yakni potensi yang dapat mengancam dirinya baik karena kesalahan dirinya, misalnya dengan ancaman hukuman mati atau karena hak-haknya yang dilanggar atau tidak terpenuhi di tempat di mana ia bekerja. Untuk itu, perjanjian kerja seharusnya bersifat menyeluruh tidak hanya mengatur perlindungan hukum menurut hukum dan perundang-undangan yang berlaku di Indonesia tetapi juga yang berlaku di negara di mana ia bekerja. Sejalan dengan hal ini, Romli Atmasasmita mengatakan, Apabila suatu negara masih mengakui jurisdiksi teritorial hukum nasional suatu negara, maka setiap penanggulangan pelanggaran hukum yang bersifat transnasional atau internasional dengan sendirinya hampir tidak dapat dilaksanakan tanpa bantuan atau kerjasama antara negara satu dengan lainnya, seperti kerjasama bilateral atau mulilateral. ${ }^{1}$

Konstruksi hukum perjanjian tenaga kerja internasional harus bersifat menyeluruh, artinya Negara Indonesia harus membuat

\footnotetext{
1 Romli Atmasasmita, Pengantar Hukum Internasional, (Bandung: PT. Fresco, 1995), hlm. 31.
} 
perjanjian tenaga kerja secara spesifik dan bilateral antara Pemerintah Indonesia dengan Pemerintah Arab Saudi, Malaysia, Taiwan, Hong Kong, Kuwait, Singapura, Persatuan Emirat Arab, Brunei Darussalam, Oman dan Yordania, dan sebagainya. ${ }^{2}$ Bentuk perjanjian seperti ini sering disebut Government to Government ( $\mathrm{G}$ to $\mathrm{G}$ ). Melalui konstruksi hukum $G$ to $G$ ini bisa menjadi dasar hukum perjanjian yang akan dibuat perjanjian antara calon tenaga kerja Indonesia dengan perusahaan pengerah tenaga kerja Indonesia; dan antara perusahaan pengerah tenaga kerja di Indonesia dengan perusahaan penerima tenaga kerja Indonesia di negara tujuan; serta antara tenaga kerja Indonesia dengan perusahaan penerima tenaga kerja Indonesia di negara tujuan. Keseluruhan perjanjian ini sering disebut dengan Private to Private atau disingkat $P$ to $P$. Perlindungan tenaga kerja Indonesia di luar negeri yang perlu dicermati adalah perjanjian yang dilakukan antara $P$ to $P$ (Private to Private) baik yang dilakukan di Indonesia maupun di negara tujuan tenaga kerja Indonesia. Di sini terdapat dua perlakuan ketentuan hukum yang perlu dicermati yakni pertama adalah asas kebebasan antara calon tenaga kerja Indonesia dengan perusahaan pengerah tenaga kerja Indonesia sebagaimana diatur dalam Pasal 1338 ayat (1) KUHPerdata. Apakah konstruksi hukum perjanjian tersebut telah memuat atau tidak unsur perlindungan hukum tenaga kerja Indonesia sebagaimana diatur dalam Pasal 3 huruf $b$ Undang-Undang No. 39 Tahun 2004 tentang Penempatan dan Perlindungan Tenaga Kerja Indonesia di Luar Negeri jo Undang-Undang No. 13 Tahun 2003 tentang Ketenagakerjaan sehingga hak-hak tenaga kerja Indonesia di negara tujuan dapat terlindungi.

\footnotetext{
${ }^{2}$ Ministry of Labour and Transmigration, Republic of Indonesia, "Protection of Women Migran Workers: Indonesia's experience" (Makalah disampaikan pada UNIFEM Regional Workshop on Protecting Women Migrant Women in Asia Meeting the Challenges, Jakarta, 9 - 11 Desember 2003), hlm. 3
}

Perlindungan hukum di luar negeri bagi tenaga kerja Indonesia oleh Pemerintah Indonesia dapat dilakukan dengan kerangka membangun hubungan bilateral dan multilaterial khususnya dengan negara-negara yang terkait dengan pengiriman tenaga kerja Indonesia ke luar negeri. Dalam kerangka membangun hubungan bilateral, Pemerintah Indonesia dapat melakukan kerjasama bidang hukum ketenagakerjaan mengenai pola dan bentuk kerjasama yang dilakukan khususnya yang terkait dengan perjanjian kerja internasional ang dibuat oleh swasta Indonesia dengan pihak negara sahabat terkait dengan masalah perlindungan hukum. Kerangka ini ditetapkan dalam bentuk Nota Kesepahaman Ketenagakerjaan (Memorandum of Understanding for Manpower, (MoU). Kerangka perlindungan hukum bagi tenaga kerja Indonesia baik yang disampaikan dan diajukan pada ASEAN, IOC ataupun ILO dapat diimplementasikan dalam kerangka bilateral, sehingga perjanjian kerja internasional meliputi pihak Indonesia yang meliputi PPTKIS dan Pemerintah Indonesia, dan pihak di mana tenaga kerja Indonesia bekerja diwakili oleh Pemerintah negara penerimaan untuk memberikan perlindungan hukum.

Kontruksi hukum tiga pihak dapat memberikan akses bagi Pemerintah Indonesia dalam memberikan bantuan hukum lebih cepat dan mudah jika terjadi pelanggaran hukum baik yang dilakukan tenaga kerja Indonesia atau sebaliknya dapat memberikan akses kepada pemerintah negara di mana tenaga kerja Indonesia untuk memberikan sanksi hukum kepada warganya dalam hal melakukan pelanggaran hukum. Ini merupakan kerangka timbal balik yang adil dalam perlindungan hukum bagi tenaga kerja Indonesia. Kondisi seperti apa yang penulis gambarkan menjadi hal sangat menarik untuk dibahas di mana kerangka perlindungan hukum untuk tenaga kerja Indonesia belum berjalan maksimal sebagaimana yang diharapkan menurut hukum dan perundang-undangan berlaku yakni memberikan perlindungan hukum baik untuk te- 
naga kerja yang bekerja di dalam negeri maupun di luar negeri. Karena banyak kasus perlakuan tenaga kerja yang terlambat untuk diberikan bantuan hukum atau perlakuan tenaga kerja Indonesia yang tidak adil selama bekerja yang mengalami berbagai penyiksaan yang tidak ditindak lanjuti proses hukum. Hal ini karena lemahnya perlindungan hukum yang dimuat dalam perjanjian kerja. Karena perjanjian hanya dibuat antara calon tenaga tenaga kerja dengan Perusahaan Jasa Tenaga Kerja Indonesia yang dibuat tidak berdasarkan standar perjanjian kerja internasional. Konstruksi hukum perjanjian kerja tidak memberikan rasa keadilan khususnya bagi tenaga kerja Indonesia yang bekerja di luar negeri. Untuk itu konstruksi hukum perjanjian kerja harus difokuskan yang dapat memberikan perlindungan kerja, khususnya bagi tenaga kerja Indonesia.

\section{PERMASALAHAN}

Adapun permasalahannya adalah sebagai berikut:

a. Bagaimanakah bentuk perjanjian kerja tenaga kerja Indonesia yang bekerja di luar negeri?

b. Bagaimanakah perlindungan hukum terhadap tenaga kerja Indonesia yang bekerja di luar negeri?

\section{RUANG LINGKUP}

Ruang lingkup pembahasan dalam penelitian ini difokuskan pada hal-hal yang berkenaan dengan perjanjian dan perlindungan TKI di luar negeri sesuai dengan ketentuan pera-turan perundang-undangan yang berlaku.

\section{METODE PENELITIAN}

Penelitian ini menggunakan penelitian hukum yuridis normatif, yaitu penelitian hukum yang menitikberatkan pada analisis peraturan hukum di mana penelitian hukum ini mengutamakan data sekunder berupa hukum positif dan bagaimana implementasinya dalam praktek.

\section{SPESIFIKASI PENELITIAN}

Spesifikasi penelitian ini adalah bersifat deskriptif analitis, ${ }^{3}$ yaitu penelitian yang dilakukan dengan memaparkan peraturan perundang-undangan yang berlaku dikaitkan dengan teori hukum dan praktik pelaksanaan hukum positif yang melalui penelitian ini diharapkan memperoleh gambaran secara kompherensif mengenai perjanjian kerja tenaga kerja ke luar negeri.

\section{PEMBAHASAN \\ Bentuk Perjanjian Kerja Tenaga Kerja Indonesia Yang Bekerja Di Luar Negeri}

Tindakan awal perlindungan hukum tenaga kerja Indonesia di luar adalah sebagaimana dimaksud Pasal 27 Undang-Undang Nomor 39 Tahun 2004 tentang Penempatan dan Perlindungan Tenaga Kerja Indonesia di Luar Negeri, adalah dilakukan dengan negara tujuan yang pemerintahnya telah membuat perjanjian tertulis dengan Pemerintah Indonesia atau tenaga kerja asing. Dalam hal ini, pemerintah Indonesia menetapkan negara tertentu itu adalah alasan keamanan, maka pemerintah menetapkan negara-negara tertentu tertutup bagi penempatan Tenaga Kerja Indonesia. Tanpa ada-nya hubungan bilateral atau multilateral yang telah disepakti, maka hal tersebut dapat mempersulit proses penyelesaian jika terjadi sengketa masalah tenaga kerja Indonesia. Misalnya, penempatan tenaga kerja Indonesia di Israel, negara ini tidak memiliki hubungan diplomatik atau hubungan bilateral, maka tidak mungkin lahir perjanjian kerjasama penempatan tenaga kerja Indonesia dengan negara tersebut, sekalipun Pemerintah Israel memiliki hukum yang melindungi tenaga kerja asing yang bekerja di negara tersebut. Walaupun hubungan bilateral atau multilateral terlihat agak kontraktif dengan penjelasan Pasal 27 ayat (2) Undang-Undang Nomor 39 Tahun 2004 tentang Penempatan dan Perlindungan Tenaga Kerja Indonesia di Luar Negeri, ka-

3 Bambang Waluyo, Penelitian Hukum dalam Praktek, Sinar Grafika, Jakarta, 1991, hlm. 18. 
rena yang dimaksud dengan tertutup untuk penempatan tenaga kerja Indonesia tidak djelaskan secara implisit maupun eksplisit dalam penjelasan Pasal 27 ayat (2) tersebut, tertutup hanya dilakukan karena pertimbangan keamanan pada ayat ini antara lain negara tujuan dalam kendaan perang, bencana alam atau terjangkit penyakit menular" tetapi bukan karena tidak adanya hubungan diplomatik, tetapi perjanjian penempatan kerjasama tenaga Kerja Indonesia harus diketahui oleh Perwakilan Indonesia di negara tujuan terebut, berarti perjanjian kerjasama Penempatan Tenaga Kerja harus memiliki hubungan bilateral atau multilateral, seperti ASEAN, Islamic Confrence Organization atau yang sejenisnya.

Perjanjian kerjasama penempatan dapat dilakukan antara Pelaksana Penempatan Tenaga Kerja Indonesia dengan Pelaksana Penempatan Tenaga di Luar Negeri dilakukan dengan hubungan bilateral atau multilateral dengan negara yang menjadi tujuan tenaga kerja Indonesia. Tanpa hubungan ini, maka perjanjian kerjasama tidak mungkin dapat dilaksanakan. Karena perjanjian ini merupakan dasar perjanjian penempatan kerja tenaga kerja Indonesia yang harus dimiliki oleh setiap instansi pelaksana penempatan tenaga kerja Indonesia. Artinya setiap pelaksana penempatan tenaga kerja Indonesia harus memiliki perjanjian ini. Dengan demikian, perjanjian ini dibuat dengan dasar private to private. Perjanjian kerjasama penempatan Tenaga Kerja Indonesia merupakan dasar perjanjian antara satu unit pelaksana penempatan tenaga kerja Indonesia dengan unit pelaksana penempatan tenaga kerja di negara tujuan, merupakan perjanjian induk (main agreement) dalam perjanjian penempatan tenaga kerja Indonesia. Perjanjian ini tidak dijelaskan secara spesifik dalam Undang-Undang Nomor 39 Tahun 2004 tentang Penempatan dan Perlindungan Tenaga Kerja Indonesia di Luar Negeri. Namun pengaturan perjanjian ini dapat dibagi dari dua sisi pertimbangan yang harus diperhatikan terkait dengan subjek hukum. Pertama adalah personalia yang ber- tindak melakukan penanda tanga-nan perjanjian, dan kedua badan hukum yang terlibat dalam perjanjian kerjasama penempatan Tenaga Kerja Indonesia.

Pertama, yakni personalia yag bertindak melakukan penandatanganan perjanjian baik yang berada di Indonesia maupun yang berada di negara tujuan. Pengakuan hukum terhadap subjek hukum ini adalah berdasarkan asas domicile of choice yakni tempat kediaman permanen seseorang dibuktikan dari fakta kehadiran seseorang secara tetap di suatu tempat tertentu dan indikasi tempat itu memang dipilih atas dasar kemauan bebasnya (factum et animus) ${ }^{4}$ Oleh karena itu, berdasarkan asas ini, maka subjek hukum yang melakukan penandantangan dapat dimungkinkan. Hal ini didasarkan beberapa hal tersendiri terhadap penggunaan asas domicile yang terlalu ketat membawa persoalan tersendiri bahwa asas ini terlihat lebih mudah diketahui di mana seseorang ia berdomisili.

Kedua, badan hukum yang terlibat dalam perjanjian kerjasama penempatan Tenaga Kerja Indonesia harus dilaksanakan melalui badan hukum. Dengan demikian kerjasama penempatan tenaga kerja Indonesia dengan pihak asing tidak mungkin dilakukan tanpa adanya status badan hukum. Maka menurut hukum perdata internasional diterapkan asas centre of administration/business. Asas ini beranggapan bahwa suatu status dan kewenangan juridis suatu badan hukum harus ditunduk pada kaidah hukum dari tempat yang merupakan pusat kegiatan administrasi badan hukum tersebut. Teori ini menghendaki agar hukum dari suatu tempat di mana suatu badan hukum memuasatkan kegiatan bisnis atau manajemennya harus digunakan untuk mengatur status juridis badan hukum terebut..$^{5}$ Oleh karena itu, asas

4 Bayu Hardjowahono, Dasar-Dasar Hukum Perdata Internsional, Buku Ke Satu, Edisi Keempat, (Bandung: Citra Aditya Bakti, 2006), hlm. 270-271

${ }^{5}$ Xanthaki, The establishment of foreign companies in France, 17 The Company Lawyer (1996), Asas ini sering disebut dengan the doctrine of siege social , Siège social (French, usually translated Head Office) is a concept in international law for determining the nationality of companies. 
ini berlaku dalam dua yakni untuk pelaksana penempatan tenaga kerja Indonesia memiliki kewenangan di Indonesia yang berwewenang untuk mencari calon tenaga kerja Indonesia yang akan ditempatkan bekerja di luar negeri, dan pelaksana penempatan tenaga kerja di negara tujuan bertanggung jawab untuk menyalurkan tenaga kerja tersebut namun ketika berada di negara tujuan, maka berlakulah asas domicile. Artinya, Tenaga Kerja Indonesia harus mematuhi segala bentuk hukum dan perundang-undangan yang berlaku di negara tujuan. Dengan demikian dalam rangka penyusunan perjanjian kerjasama itu selain tetap me-nerapkan asas konsensual sebagaimana diatur dalam Pasal 1320 KUHPerdata, juga harus diberikan pengaturan mengenai asas domicilie ini, sehingga perjanjian kerjasama penempatan tenaga kerja Indonesia bersifat dinamis. Karena perjanjian kerjasama penempatan tenaga kerja Indonesia tidak diatur secara spesifik, tetapi untuk membuat perjanjian ini hanya didasarkan pada Pasal 1 ayat (8) Penempatan dan Perlindungan Tenaga Kerja Indonesia di Luar Negeri yang menyatakan, "Perjanjian Kerja Sama Penempatan adalah perjanjian tertulis antara pelaksana penempatan Tenaga Kerja Indonesia swasta dengan mitra usaha atau Pengguna yang memuat hak dan kewajiban masing-masing pihak dalam rangka penempatan serta perlindungan Tenaga Kerja Indonesia di negara tujuan"6

Konstruksi hukum perjanjian kerjasama penempatan tenaga kerja ini terdapat tiga hal yang dipertimbangkan yakni kepentingan pelaksana penempatan tenaga kerja Indonesia yakni harus tetap menjaga kelangsungan hidup usaha dan memupuk keuntungan dengan memberikan jaminan perlindungan hukum terhadap tenaga kerja Indonesia yang ditempatkan di negara tujuan. Jaminan perlindungan hukum merupakan tujuan utama, karena tanpa perlindungan

\footnotetext{
${ }^{6}$ Pasal 1 ayat (8), Undang-Undang Nomor 39 Tahun 2004 tentang Penempatan dan Perlindungan Tenaga Kerja Indonesia di Luar Negeri.
}

hukum maka tidak mungkin dapat tercapai penempatan di negara tujuan tersebut. Kepentingan kedua, adalah kepentingan pelaksana penempatan tenaga kerja di negara tujuan. Memang, tujuan kepentingan kedua adalah sama dengan kepentingan pertama. Namun kepentingan kedua di negara tujuan lebih terfokus kepada pemberian jaminan perlindungan hukum di negara tujuan tersebut. Oleh karena itu, untuk lebih memberikan jaminan nyata dalam perlindungan hukum baik bagi tenaga kerja Indonesia di negera tujuan dan wujud nyata pemberian perlindungan hukum bagi tenaga kerja Indonesia di negara tujuan, maka perjanjian kerjasama penempatan ini diketahui dan disetujui oleh masing-masing Pemerintah yang terlibat dalam kerjasama penempatan tenaga kerja Indonesia di luar negeri. Pihak Indonesia diwakili oleh Perwakilan Indonesia negara tujuan.

Dalam perjanjian kerjasama penempatan tenaga kerja Indonesia diketahui oleh kedua pemerintahan berarti apa yang dilakukan oleh tenaga kerja Indonesia di negara tujuan itu sudah benar memperoleh legalitas dan masuk dalam negara itu dengan tujuan formal yang bekerja. Artinya, akitivas hubungan kerja sudah legal, dan memperoleh perlindungan hukum bila terjadi masalah dalam masalah ketenagakerjaan. Bagi Pemerintah Indonesia, perjanjian kerjasama penempatan tenaga kerja Indonesia adalah sebagai upaya untuk memberikan perlindungan hukum kepada warga negaranya yang bekerja di luar negeri. Perlindungan hukum sudah menjadi tugas pemerintah. Hal dimaksudkan itu ditegaskan dalam Undang-Undang Dasar 1945 menentukan bahwa negara berkewajiban melindungi segenap bangsa Indonesia dan seluruh tumpah darah Indonesia. Perlindungan dimaksudkan itu meliputi pula perlindungan warga negara yang berada di luar negeri sehingga negara berkewajiban melakukan pencegahan dan penanggulangan terhadap perlakuan yang tidak adil terhadap tenaga kerja Indonesia yang ada di luar negeri.Untuk mewujudkan pencegahan dan penanggula- 
ngan tersebut, ditegaskan dalam konsideran huruf d Undang-Undang Nomor 39 Tahun 2004 tentang Penempatan dan Perlindungan Tenaga Kerja Indonesia di Luar Negeri yang me-nyatakan sebagai berikut, "bahwa negara wajib menjamin dan melindungi hak asasi warga negaranya yang bekerja baik di dalam maupun di luar negeri berdasarkan prinsip persamaan hak, demokrasi, keadilan sosial, keseteraan dan keadilan gender, anti diskriminasi dan anti perdagangan manusia"7 $^{\text {, }}$

Konstuksi ketiga dalam perjanjian kerjasama penempatan adalah tenaga kerja Indonesia. Menurut konstruksi ini, tenaga kerja Indonesia sebagai objek hukum. Sebenarnya, pengertian objek hukum adalah bukan manusia tetapi benda. Bentuk perjanjian seharusnya dilarang, perjanjian ini dianggap tidak melanggar hukum bila objek hukum itu harus memenuhi beberapa kriteria, jika tidak, maka perbuatan itu merupakan tindakan melanggar hak asasi manusia atau dianggap tindakan perbudakan.

\section{Perlindungan Hukum Tenaga Kerja In-} donesia yang Bekerja di Luar Negeri

Upaya perlindungan hukum dan mediasi penyelesaian masalah Tenaga Kerja Indonesia yang telah dilakukan oleh pemerintah melalui tindakan preventif-antisipatif seperti penyempurnaan regulasi yang telah dinyatakan dengan diundangkannya Undang-Undang Nomor 39 Tahun 2004 tentang Penempatan dan Perlindungan Tenaga Kerja Indonesia di Luar Negeri. Upaya ini menghasilkan efek sinegis dengan pembenahan mekanisme, pembuatan regulasi lainnya, penetapan instrumen perlindungan hukum, standar kualitas Tenaga Kerja Indonesia dan sekaligus pengawasan sebagai upaya perlindungan dan kepastian hukum melalui penciptaan perjanjian yang berhubungan dengan penempatan kerja baik yang dibuat di Indonesia maupun di luar negeri. Sedangkan upaya preventif adalah bersifat integratif dan komprehensif adalah upaya

\footnotetext{
${ }^{7}$ Undang-Undang Nomor 39 Tahun 2004, op. cit, Konsideran huruf d
}

untuk mengintegrasikan perjanjian yang terkait dengan penempatan tenaga kerja Indonesia di luar negeri. Upaya ini dapat berlaku universal dan komprehensif artinya dapat digunakan di negara tujuan negara kerja mana saja.

Upaya perlindungan di dalam negeri yang dilakukan oleh Direktorat Perlindungan dan Advokasi adalah pencegahan dan penindakan terhadap Tenaga Kerja Indonesia non prosedural yang dilakukan melalui sweeping terhadap pelaksana penempatan Tenaga Kerja Indonesia non prosedural. Pola pelaksanaan tenaga kerja ini dapt dianggap sebagai upaya perbudakan modern dan tidak memperoleh perlindungan hukum. Upaya sweeping merupakan pencegahan awal (early protection) dalam perlindungan hukum, Upaya ini dilakukan oleh Departemen Tenaga Kerja dan Transmigrasi bekerja sama dengan pihak Kepolisian. ${ }^{8}$ Upaya kedua adalah melalui pencegahan premanisme terhadap Tenaga Kerja Indonesia di pelabuhan embarkasi dan debakasi yang dilakukan oleh Departemen Tenaga Kerja dan Transmigrasi bekerja sama dengan pihak Kepolisian, Departemen Hukum dan HAM, Departemen Perhubungan. ${ }^{9}$ Ketiga, kerjasama dan koordinasi antar instansi dalam penanganan deportasi tenaga kerja Indonesia khususnya dari Malaysia. ${ }^{10}$ dan keempat adalah pelayanan pemulangan Tenaga Kerja Indonesia dan juga kerjasama dengan lembaga internasional seperti IOM dan ILO untuk pencegahan trafficking in person ${ }^{11}$

Untuk memberikan perlindungan hukum kepada tenaga kerja Indonesia yang selama ini dilakukan pemerintah adalah sebagai berikut:

1. Pencegahan dan penindakan terhadap penempatan Tenaga Kerja Indonesia Non Prosedural (Preventif dan Represif)

\footnotetext{
${ }^{8}$ Direktorat Perlindungan dan Advokasi, op.cit, hlm. 29

${ }^{9}$ Ibid.hlm.30

${ }^{10}$ Ibid.

${ }^{11}$ Ibid.
} 
Dalam rangka memberikan perlindungan hukum kepada Tenaga Kerja Indonesia terhadap praktek penempatan Tenaga Kerja Indonesia illegal, maka pemerintah melalui Badan Nasional Penempatan dan Perlindungan Tenaga Kerja Indonesia berdasarkan Pasal 95 aya (2) UndangUndang Nomor 39 Tahun 2004 tentang Penempatan dan Perlindungan Tenaga Kerja Indonesia di Luar Negeri yang menyatakan sebagai berikut:

Untuk menyelesaikan fungsi sebagaimana dimaksud pada ayat (1), Badan Nasional Penempatan dan Perlindungan Tenaga Kerja Indonesia bertugas:

a. melakukan penempatan atas dasar perjanjian secara tertulis antara Pemerintah dengan Pemerintah negara Pengguna Tenaga Kerja Indonesia atau Pengguna berbadan hukum di negara tujuan penempatan sebagaimana dimaksud dalam Pasal 11 ayat (1);

b. memberikan pelayanan, mengkoordinasikan, dan melakukan pengawasan mengenai:

- dokumen;

- pembekalan akhir pemberangkatan (PAP);

- penyelesaian masalah;

- sumber-sumber pembiayaan;

- pemberangkatan sampai pemulangan;

- peningkatan kualitas calon Tenaga Kerja Indonesia;

- informasi;

- kualitas pelaksana penempatan Tenaga Kerja Indonesia; dan

- peningkatan kesejahteraan Tenaga Kerja Indonesia dan keluarganya.

Tugas di atas merupakan tugas Badan Nasional Penempatan dan Perlindungan Tenaga Kerja Indonesia untuk melakukan tindakan terhadap Perusahaan Pelaksana Tenaga
Kerja Indonesia Swasta dan/atau non Perusahaan Pelaksana Tenaga Kerja Indonesia Swasta (perseorangan, perusahaan dan/atau organisasi) yang diduga kuat melakukan penempatan Tenaga Kerja Indonesia ke luar negeri secara non prosedural, beradasarkan adanya pengaduan, pemberitaan media massa, dan lain-lain yang selanjutnyae diperkuat melalui penyelidikan. Ancaman atau sanksi yang dikenakan meliputi sanksi administratif dan sanksi pidana yang termaksud dalam Pasal 100, 102, 103 dan 104 Undang-Undang Nomor 39 Tahun 2004 tentang Penempatan dan Perlindungan Tenaga Kerja Indonesia di Luar Negeri. Penanganan kasusnya adalah sebagai berikut:

a. Sanksi Administratif

Sanksi administratif diberikan kepada Perusahaan Penempatan Tenaga Kerja Indonesia Swasta. Oleh karena itu, apabila dalam tempo sekurang-kurangnya 10 (sepuluh) hari ternyata tidak ditemukan adanya tindak pidana (untuk Perusahaan Penempatan Tenaga Kerja Indonesia Swasta) atau dapat ditemukan adanya pelanggaran administratif, maka berdasarkan Berita Acara Pemeriksaan dan laporan hasil pemeriksaan, maka Direktur Perlindungan dan Advokasi membuat surat rekomendasi pengenaan sanksi administratif terhadap Perusahaan Penempatan Tenaga Kerja Indonesia Swasta yang terbukti melakukan pelanggaran, yang ditujukkan kepada Direktur Jenderal PPTKLN atau Menteri Tenaga Kerja dan Transmigrasi. Sanksi administratif diatur dalam Peraturan Menteri Tenaga Kerja dan Transmigrasi No. PER-05/MEN/III/2005 tentang Ketentuan Sanksi Administratif dan Tata Cara Penjatuhan Sanksi Dalam Pelaksanaan Penetapan dan Perlindungan Tenaga Kerja Indonesia di Luar Negeri.

b. Sanksi Pidana

Sanksi pidana dijatuhkan setelah dilakukan sweeping terhadap Perusa- 
haan Penempatan Tenaga Kerja Indonesia Swasta yang diduga kuat adanya tindak pidana yang dilakukan oleh Perusahaan Penempatan Tenaga Kerja Indonesia Swasta dan/atau non Perusahaan Penempatan Tenaga Kerja Indonesia Swasta oleh penyidik pegawai negeri sipil (PPNS) dan/atau Penyidik Polri.

2. Pencegahan Preemanisme Terhadap Calon Tenaga Kerja Indonesia/ Tenaga Kerja Indonesia di Pelabuhan Emabarkasi dan Debarkasi Tindakan ini dilaksanakan melalui koordinasi antara Departemen Tenaga Kerja dan Transmigrasi dengan instansi terkait seperti Kepolisian, Departemen Hukum dan HAM, Departmen Perhubungan, Kantor Administrasi Bandar Udara, Kantor Administrasi Pelabuhan, Pemerintah Daerah, Perum Angkasa Pura.

3. Penanganan Kasus Tenaga Kerja Indonesia

Masalah atau kasus Tenaga Kerja Indonesia dapat diketahui melalui adanya pengaduan, berita media massa, surat dan lain-lainnya. Secara hukum, baik penanganan kasus di dalam negeri maupun di luar negeri adalah didasarkan pada perjanjian kerjasama penempatan, perjanjian penempatan kerja dan perjanjian. Karena tiga perjanjian ini merupakan konstruksi hukum yang dibangun untuk mengatasi penyelesaian kasus. Dalam perjanjian kerja antara Tenaga Kerja dan Pengguna Tenaga Kerja, perjanjian tersebut diketahui oleh Perwakilan Republik Indonesia di luar negeri yang didasarkan pada Pasal 78, 80 dan 106 Undang-Undang Nomor 39 Tahun 2004 tentang Penempatan dan Perlindungan Tenaga Kerja Indonesia di Luar Negeri. Hal-hal yang dilakukan setelah Perwakilan Republik Indonesia melakukan koordinasi, maka dikukan sebagai berikut: a. Memberikean bantuan hukum sesuai dengan ketentuan peraturan perundang-undang yang berlaku dan berdasarkan keangka perjanjian kerjasama penempatn, perjanjian penempatan teaga kerja Indonesia di negara tujuan serta hukum dan kebiasaan internsional.

b. Pembelaan atas pemenuhan hak-hak sesuai dengan perjanjian kerja dan/atau peraturan perundang-undangan di negara Tenaga Kerja Indonesia ditempatkan.

c. Memberikan rekomendasi kepada Dirjen PPTKLN atau Menteri Tenaga Kerja dan Transmigrasi untuk memberikan sanksi administratif kepada Perusahaan Pelaksana Tenaga Kerja Indonesia swasta dan mitra usaha atau pengguna bila terbukti melakukan pelanggaran terhadap peraturan perundang-undangan di bidang penempatan dan perlindungan tenaga kerja di Indonesia.

4. Penyelasaian Masalah Non Litigasi melalui Mediasi

Untuk melakukan mediasi atau perundingan dipimpin oleh Mediator yang ditunjuk oleh instansi pemerintah yang membidangi ketenagakerjaan. Karena perundingan dapat berlangsung singkat dan juga berlangsung lama, selanjutnya mediasi dibagi menjadi dua tahapan, yakni mediasi awal dan mediasi lanjutan.

a. Mediasi awal

Mediasi awal adalah perundingan bagi masalah atau kasus Calon Tenaga Kerja Indonesia/ Tenaga Kerja Indonesia yang baru pertama kali diadukan dengan cara mempelajari kasus, menganalasis dokumen kasus calon Tenaga Kerja Indonesia/ Tenaga Kerja Indonesia dan mempelajari perjanjian kerja yang telah dibuat dan juga perjanjian yang telah dibuat oleh Pelaksana Penempatan Tenaga Kerja Indonesia dengan Pelaksana Penempatan Tenaga Kerja 
di negara tujuan atau perjanjian kerjasama sebagai bahan dalam pengambilan tindakan hukum pada proses mediasi. Di negara tujuan, proses mediasi ini difasilitasi oleh Perwakilan Republik Indonesia, Perwakilan Perusahaan Pelaksana Tenaga Kerja Indonesia di negara tujuan dan Pelaksana Tenaga Kerja di negara tujuan sebagai tindakan non litigasi.

b. Mediasi Akhir

Akhir proses mediasi dilakukan ditandai dengan selesainya perundingan. Proses mediasi ini dilakukan dengan cara perundingan untuk menghasilkan kesepakatan maupun tidak mengenai masalah yang diperselisihan. Dalam hal tercapai kesepatan, maka dibuatkan nota kesepakatan. Sedangkan perundingan yang tidak menghasilkan kesepakatan, maka mediator menyampaikan nota anjuran yang disampai di beberapa hari kemudian. Nota anjuran merupakan saran mediator guna menyelesaikan masalah yang diperselisihkan.

5. Penyelesaian Masalah Litigasi Penyelesaian litigasi adalah penyelesaian yang dilakukan melalui jalur hukum. Dalam penyelesaian litigasi dapat dibagi dua, yakni penyelesaian kasus Penempatan Tenaga Kerja Indonesia luar negeri di dalam negeri, dan kasus yang terjadi di negara tujuan.

a. Penyelesaian Masalah Tenaga Kerja Indonesia di Dalam Negeri

Penyelesaian kasus Tenaga Kerja Indonesia di dalam negeri adalah penyelesaian litigasi dalam kegiatan pra penempatan, Kasus ini biasanya terjadi terhadap praktek illegal penempatan Tenaga Kerja Indonesia ke luar negeri. Praktek illegal yang dilakukan oleh Pelaksana Penempatan Tenaga Kerja Indonesiea yang legal. Artinya praktek ini terjadi karena dilakukan tidak menurut prosedur yang telah ditetapkan. Di sini terjadi praktek trafficking in person. Praktek ini terjadi biasanya diawali dengan pengaduan Tenaga Kerja Indonesia yang disertai praktek pemalsuan dokumen tenaga kerja Indonesia, biasanya pemalsuan identitas diri, keterangan dokter, dan juga paspor. Atas pengaduan ini, maka dilakukan penindakan hukum melalui proses pengadilan.

b. Penyelesaian Masalah Tenaga Kerja Indonesia di Luar Negeri

Penyelesaian masalah litigasi di luar negeri dilakukan terhadap setiap Tenaga Kerja Indonesia di luar negeri. Peran aktif Perwakilan Republik Indonesia untuk memberikan bantuan hukum termasuk penyediaan penasehat hukum untuk menjadi pembela dalam penyelesaian kasus di pengadilan di negara tujuan. Penyelesaian dimaksudkan itu dikoordinasikan oleh Perwakilan Republik Indonesia kepada Departmen Tenaga Kerja dan Transmigrasi, Departemen Hukum dan Hak Asasi Manusia, dan juga kepada keluarga Tenaga Kerja Indonesia yang menjadi tersangka. Tindakan koordinatif merupakan tindakan yang penting untuk memberikan pembelaan hukum yang maksimal terhadap kasus yang menimpahnya. Penyelesaian litigasi dan non litigasi dalam kasus Tenaga Kerja Indonesia baik yang terjadi di dalam negeri maupun di luar negeri merupakan bentuk tanggung jawab negara dalam rangka memberikan perlindungan hukum kepada setiap tenaga kerja Indonesia swasta yang sering terjadi. Melalui perlindungan hukum inilah sebagai bentuk yang membedakan penempatan tenaga kerja yang benar-benar bekerja di luar dengan praktek perbudakan moderen atau bentuk trafficking in person. Oleh karena itu, perlindu- 
ngan hukum diterapkan melalui perjanjian kerja yang dilakukan perjanjian kerjasama penempatan yang dibuat oleh Perusahaan Pelaksana Penempatan Tenaga Kerja Indonesia dengan Pelaksana Penempatan Tenaga Kerja di Negara Tujuan; Perjanjian Penempatan Tenaga Kerja Indonesia dengan Calon Tenaga Kerja Indonesia/Tenaga Kerja Indonesia; dan Perjanjian Kerja antara Tenaga Kerja Indonesia dengan Pengguna Tenaga Kerja Indonesia di negara tujuan.

Ketiga perjanjian di atas merupakan konstruksi hukum yang harus dibuat dan atau dilahirkan menurut prinsip dan asas hukum yang tepat sehingga hak dan kewajiban antara kepentingan tenaga kerja Indonesia, Pemerintah Indonesia dan pengguna $\mathrm{Te}$ naga Kerja Indonesia ataupun kepentingan Perwakilan Pelaksana Calon Tenaga Kerja di negara tujuan. Karena seluruh proses hukum dan non hukum karena tetap merujuk pada ketiga konstruksi hukum yang dibuat baik itu penyelesaian di dalam negeri maupun penyelesaian di luar negeri. Jika tiga perjanjian kerja dalam konstruksi hukum lemah, maka akan sangat mungkin lemah pula posisi hukum Calon Tenaga Kerja Indonesia dalam penyelesaian kasus. Sebaliknya, jika kuat, maka posisi hukum akan kuat pula. Dengan demikian untuk memberdayakan tenaga kerja Indonesia yang ditempatkan di luar negeri yang terlebih dahulu dan perhatikan adalah konstruksi hukum perjanjian hukum yang terkait dalam penempatan kerja.

\section{KESIMPULAN}

Berdasarkan analisa pembahasan yang telah diuraikan di atas, selanjutnya penulis mencoba membuat beberapa kesimpulan adalah sebagai berikut:
1. Bentuk perjanjian kerja tenaga kerja Indonesia yang bekerja di luar negeri berbentuk perjanjian kerjasama penempatan merupakan dasar utama perjanjian yang harus dilakukan pada setiap ingin melakukan penempatan tenaga kerja Indonesia ke luar negeri. Hal ini didasarkan pada Pasal 27 UU No. 39 Tahun 2004 mengatur mengenai penempatan baru dapat dilakukan bila Pemerintah Indonesia telah membuat perjanjian tertulis dengan pemerintah negara tujuan. Aturan ini bertujuan memberikan perlindungan hukum kepada setiap warga negara Indonesia. Perlindungan hukum sangat penting bila konflik tenaga kerja Indonesia dengan perusahaan di mana ia bekerja di luar negeri. Perjanjian Kerjasama Penempatan dapat dijadikan dasar pertimbangan hukum untuk melakukan penyelesaian hukum selanjutnya.

2. Perlindungan hukum terhadap tenaga kerja Indonesia yang bekerja di luar negeri adalah dimulai dengan perlindungan di dalam negeri yang dilakukan oleh Direktorat Perlindungan dan Advokasi adalah pencegahan dan penindakan terhadap Tenaga Kerja Indonesia non prosedural yang dilakukan melalui sweeping terhadap pelaksana penempatan Tenaga Kerja Indonesia non prosedural. Perlindungan hukum dan mediasi penyelesaian masalah Tenaga Kerja Indonesia yang telah dilakukan oleh pemerintah melalui tindakan preventif-antisipatif seperti penyempurnaan regulasi yang telah dinyatakan dengan diundangkannya Undang-Undang Nomor 39 Tahun 2004 tentang Penempatan dan Perlindungan Tenaga Kerja Indonesia di Luar Negeri. Upaya ini menghasilkan efek sinegis dengan pembenahan mekanisme, pembuatan regulasi lainnya, penetapan in- 
strumen perlindungan hukum, standar kualitas Tenaga Kerja Indonesia dan sekaligus pengawasan sebagai upaya perlindungan dan kepastian hukum melalui pencipta-an perjanjian yang berhubungan dengan penempatan kerja baik yang dibuat di Indonesia maupun di luar negeri

\section{SARAN}

Berdasarkan kesimpulan di atas, selanjutnya penulis mencoba membuat beberapa saran adalah sebagai berikut:

1. Pemerintah Indonesia harus selektif dalam membuat perjanjian kerja sama tenaga kerja dengan negara tujuan tenaga kerja Indonesia bekerja. Upaya ini memang harus dipersiapkan betul agar dalam perlindungan hukum dapat diselesaikan dengan baik dan benar sehingga tidak ada satupun warga negara Indonesia yang dirugikan karena kelemahan Perjanjian Kerja antar negara khususnya perjanjian kerja bersifat multilateral yang sering diperlakukan tidak manusiawi.

2. Perjanjian Penempatan Tenaga Kerja Indonesia merupakan titik awal perjanjian tenaga kerja antara pencari kerja dengan perusahaan pengerah tenaga kerja Indonesia. Titik awal ini seharusnya Pemerintah Indonesia dalam upaya menegakkan UU No. 39 Tahun 2004 dan UU No. 13 Tahun 2003 adalah dengan lebih banyak memberikan perhatian dan pengawasan khusus sehingga hak-hak pekerja dapat terlindungi sebelum dan setelah bekerja di luar negeri. Ini merupakan bagian tugas negara untuk melindungi setiap warga negaranya. Dalam perjanjian kerja dibuat di negara di mana tenaga kerja Indonesia bekerja yakni antara majikan dan atau perusahaan tempat tenaga kerja Indonesia bekerja. Di sini juga tenaga kerja Indonesia harus diberikan perlindungan hukum dengan mengintensifkan pengawasan khusus perwakilan RI di luar negeri untuk mengawasi proses perjanjian kerja sehingga hak dan kewajiban tenaga kerja Indonesia dapat terlindungi. 


\section{DAFTAR PUSTAKA}

\section{Buku-Buku:}

Adrian Sutedi,Hukum Perburuhan, Jakarta: Sinar Grafika, 2009

Agusmidah, 2010. Hukum Ketenagakerjaan Indonesia. Bogor : Ghalia Indonesia.

Atmasasmita, 1995, Romli., Pengantar Hukum Internasional, Bandung: PT. Fresco.

Anwar, Dewi Fortuna., Human Security: An Intratable Problem in Asia, dalam Muthiah Algappa (ed), Asian Security Order: Instrumental and Normantive Features, Stanford: Stanford University Press, 2003.

Bayu Seto Hardjowahono, Dasar-Dasar Hukum Perdata Internasional, Buku Kesatu, Edisi Keempat, Bandung: PT. Citra Aditya Bakti, 2006

Badrulzaman, Mariam Darus., Kompilasi Hukum Perkatan, Bandung: Citra Aditya Bhakti, 2001.

Cheshire, G.C., North, P.M., dan Fawcett, J., Private International Law, Edisi 13, Oxford, Oxford University Press, 2004.

Darwan Prints, 2000. Hukum Ketenagakerjaan Indonesia. Bandung : PT Citra Aditya

Bakti.

Dewi Rahayu, Hukum Ketenagakerjaan Teori dan Studi Kasus,(Yogyakarta: Elmatera Publisher,2011

Djumadi, Hukum Perburuhan Perjanjian Kerja,Jakarta:RajaWali Pers,2004

Djumialdji, FX, 2007.Perjanjian Kerja, Jakarta : Penerbit Bumi Aksara

Direktorat Perlindungan dan Advokasi, Pola Kerjasama Bantuan Tenaga Kerja Luar Negeri, Jakarta: Direktorat Jenderal Pembinaan dan Penempatan Tenaga Kerja Luar Negeri, 2004.

Perangkat Teknis Pola Kerja Sama Batuan Hukum Tenaga Kerja Luar Negeri, Sistem Perlindungan Tenaga Kerja Indonesia, Jakarta: Direktorat Jenderal dan Penempatan Tenaga Kerja Indonesia Luar Negeri, Departemen Tenaga Kerja dan Transmigrasi, 2006.

Husni, Lalu, Hukum Ketenagakerjaan Indonesia, Edisi Revisi, Jakarta: PT. RajaGrafindo Persada, 2007.

Imam Soepomo, Pengantar Hukum Perburuhan, Jakarta: Djambatan, 2013.

Juwana, Hikmahanto., Hukum Ekonomi dan Hukum Internasional, Jakarta: Lentera Hati, 2002.

Kansil C.S.T.,Pengantar Ilmu dan Tata Hukum Indonesia, Jakarta: Balai Pustaka,2013 Harahap, M. Yahya., Hukum Acara Perdata, tentang gugatan, persidangan, penyitaan, pembuktian dan putusan pengadilan, Jakarta: Sinar Grafika, 2006.

Hardjowahono, Bayu., Dasar-Dasar Hukum Perdata Internsional, Buku Ke Satu, Edisi Keempat, Bandung: Citra Aditya Bakti, 2006.

Hartono, Judiantoro.1992.Segi Hukum Penyelesaian Perselisihan Perburuhan. Jakarta: Rajawali Pers

Manulang, 2005, Pokok-Pokok Hukum Ketenagakerjaan di Indonesia, Rineka Cipta, Jakarta, Cetakan kedua

Muchsin, Perlindungan dan Kepastian Hukum bagi Investor di Indonesia, Surakarta : Magister Ilmu Hukum Program Pascasarjana Universitas Sebelas Maret, 2013 
Roland Paris, "Human Security, A Paradigm or Hot Air"?. International Security, 26 (2), 2001.

Suprapto, R., Hubungan Internasional: sistem dan interaksi perilaku, Jakarta: PT. RajaGrafindo Persada, 1997.

Schoenhardt, Andreas., Migrant Smuggling, Illegal Migration and Organized Crime in Autralia and Asia FacificRegion, Leiden and Boston: Martinus Nijhoff Publishers, 2003.

Satjipto Raharjo, Ilmu Hukum, PT. Citra Aditya Bakti, Bandung, 2000 , Sisi-sisi Lain dari Hukum di Indonesia, Kompas, Jakarta, 2003. ,Ilmu Hukum, Cet. VI, Bandung: Citra Aditya Bakti, 2006

Salam, Moch Faisal., Penyelesaian Sengketa Bisnis secara Nasional dan Internasional, Bandung: Mandar Maju, 2007.

Subekti, Pokok-Pokok Hukum Perdata, Jakarta : PT. Intermassa, 2003.

Sudaryatmo, 2009, Hukum dan Advokasi Konsumen, PT. Citra Aditya Bakti, Bandung Tjitrosudibio, R., Kitab Undang-Undang Hukum Perdata, Jakarta: Pradnya Paramita Zainal, Asikin, 2016, Dasar-Dasar Hukum Perburuhan, PT. Raja Grafindo Persada, Jakarta.

\section{Artikel dan Makalah}

Ministry of Labour and Transmigration, Republic of Indonesia, "Protection of Women Migran Workers: Indonesia's experience" (Makalah disampaikan pada UNIFEM Regional Workshop on Protecting Women Migrant Women in Asia Meeting the Challenges, Jakarta, 9 - 11 Desember 2003)

Surapati, Surya Chandra, "RUU Perlindungan Pekerja Indonesia di Luar Negeri sebagai Upaya DPR dalam Membentuk Sistem Yang Adil dan Manusiawi" (Makalah disampaikan pada Seminar Kontraversi RUU Buruh Migran sebagai Instrumen dalam Upaya Memanusiawikan dan Melindungi Buruh Migran, Jakarta 17 Maret 2003)

Xanthaki, The establishment of foreign companies in France, 17 The Company Lawyer ,1996, at 28,Asas ini sering disebut dengan the doctrine of siege social, Siège social (French, usually translated Head Office) is a concept in international law for determining the nationality of companies

\section{Peraturan Perundang-Undangan}

Indonesia, Undang-Undang Dasar Negara Republik Indonesia Tahun 1945

Indonesia, Undang-Undang Tentang Ketenagakerjaan, UU No. 13 Tahun 2003.

Kitab Undang-Undang Hukum Perdata (Burgerlijk Wetboek), Diterjemahkan oleh R. Subekti dan R. Tjitrosudibio, Cet. 8, (Jakarta, Pradnya Paramita, 1976),

Indonesia, Undang-Undang tentang Penempatan dan Perlindungan Tenaga Kerja Indonesia di Luar Negeri, UU No. 39 Tahun 2004, LN No. 133 dan TLN No. 4445.

\section{Website}

http://hukum on line.co.id/2010/12/pembuktian-dan-alat-alat-bukti.html, diakses 14 Agustus 2019 